\title{
Operating group as a follow-up strategy of a Nursing Course's Pedagogical Project
}

\author{
Grupo operativo como estratégia para acompanhamento do Projeto Pedagógico de Curso em \\ Enfermagem
}

\author{
Grupo operativo como estrategia para acompañar el Proyecto Pedagógico del Curso en \\ Enfermería
}

Gabriella Cristine Guerra de Carvalho ${ }^{1}$, Luciano César Pereira Campos Leonel ${ }^{1}$, Maria Conceição Bernardo de Mello e Souza ${ }^{2}$, Roselma Lucchese ${ }^{1}$, Carla Natalina da Silva Fernandes ${ }^{1}$

The aim of the study was to monitor and describe the implementation process of the Pedagogical Project of the Nursing Undergraduate Course, at the Catalão Campus of the Federal University of Goiás, from the perspective of professors and students. Qualitative and descriptive study, conducted with thirteen participants, of April, 2010 and June, 2011, in Catalão, GO, Brazil. It was possible to use the operative group as a technology for monitoring and data collection. At the end of each meeting, it was possible to set up a chronicle that was subjected to the thematic content analysis. Two categories emerged and showed as potentiality: the curricular matrix interdisciplinarity, and the students' immaturity, the conflictive interpersonal relationship between students and professors as their constraints. Working in small groups and the operative group proved to be assertive in the teaching management and conducting research.

Descriptors: Education, Nursing; Faculty, Nursing; Students, Nursing; Nursing Faculty Practice; Nursing Education Research.

O objetivo do estudo foi acompanhar e descrever o processo de implantação do Projeto Pedagógico do Curso de Graduação em Enfermagem do Campus Catalão da Universidade Federal de Goiás, sob a ótica de docentes e discentes. Tratou-se de estudo qualitativo e descritivo, realizado com treze participantes entre docentes e discentes, de abril de 2010 a junho de 2011, em Catalão, GO, Brasil. Utilizou-se o grupo operativo como tecnologia para acompanhamento e coleta de dados. Ao final de cada reunião foi constituída uma crônica, submetida à análise de conteúdo temática, de onde emergiram duas categorias, que revelaram como potencialidade do processo ensino-aprendizagem a interdisciplinaridade da matriz curricular, e como limitadores a imaturidade dos estudantes e a relação interpessoal conflituosa entre acadêmicos e docentes. 0 trabalho em pequenos grupos demonstrou-se importante ferramenta pedagógica; o grupo operativo mostrou-se assertivo na gestão do ensino e na condução da pesquisa.

Descritores: Educação em Enfermagem; Docentes de Enfermagem; Estudantes de Enfermagem; Prática do Docente de Enfermagem; Pesquisa em Educação de Enfermagem.

El objetivo del estudio fue acompañar y describir el proceso de implantación del Proyecto Pedagógico del Curso de Graduación en Enfermería, en el Campus Catalão, Universidad Federal de Goiás, bajo la óptica de docentes y discentes. Estudio cualitativo y descriptivo, con trece participantes, realizado entre abril del 2010 y junio del 2011, en Catalão, G0, Brasil. Se utilizó el grupo operativo como tecnología para acompañamiento y obtención de datos. Al final de cada reunión, fue realizada una crónica, sometida al análisis del contenido temático, donde emergieron dos categorías que revelaron como potencialidad del proceso de enseñanza y aprendizaje la interdisciplinaridad de la matriz curricular, y como limitadores, la inmadurez de los estudiantes y relación interpersonal conflictiva entre discentes y docentes. El trabajo en pequeños grupos es importante herramienta pedagógica; el grupo operativo se mostró asertivo en la gestión de la enseñanza y en la conducción de la investigación

Descriptores: Educación en Enfermería; Docentes de Enfermería; Estudiantes de Enfermería; Práctica del Docente de Enfermería; Investigación en Educación de Enfermería.

\footnotetext{
${ }^{1}$ Universidade Federal de Goiás-Campus Catalão. Catalão, GO, Brazil.

${ }^{2}$ Escola de Enfermagem de Ribeirão Preto, Universidade de São Paulo. Ribeirão Preto, SP, Brazil.
}

Corresponding author: Carla Natalina da Silva Fernandes

Av. Dr. Lamartine Pinto de Avelar, 1120, Setor Universitário, CEP: 75705-220. Catalão, G0, Brazil. E-mail: carla_natalina@yahoo.com.br 


\section{Introduction}

Higher education in Brazil is facing a transition process through the implementation of public policies aimed at investments for federal institutions of higher education ${ }^{(1)}$. From the year 2003 on, programs to provide university vacancies have been fostered through various public programs in Brazil, including the program Reestruturação e Expansão das Universidades Federais [Restructuring and Expansion of Federal Universities], also leading to the process of taking Brazilian public universities to the countryside $^{(2)}$. In this process several states opted to deploy undergraduate nursing courses, but this option brings significant challenges given the demands on training competent nurses to meet the health needs of the community within the proposal of the Unified Health System ${ }^{(3)}$.

Among the challenges, one highlights the desired profile of the contemporary nursing student, that is, one that overcomes the technical skills and disarticulated theoretical knowledge, through the training of critical, creative and reflective nurses who articulate theory and practice, acting with principles of ethics and leadership ${ }^{(4)}$.

To do so, the review of the course's pedagogical project is necessary, which is the basis for academic and administrative management. It should contain the elements of philosophical, conceptual, political and methodological bases that define the skills and abilities essential to the education, revealing the guiding principles that the educational institution adopted to comply with the National Curriculum Guidelines ${ }^{(4)}$. Because besides the challenge of training competent nurses to work in the Unified Health System, managers in education and health, educators and professionals are invited to innovate their teaching technologies, through active pedagogical practices, enabling the construction of "know how to do" due to the health needs of the community and contextual diversity of the population ${ }^{(3)}$.

One also understand the pedagogical project of the course as a project in motion that undergoes changes, which influences and is influenced by those who put it into practice, agreeing with its social reality ${ }^{(4)}$. The dialogue, the search for new concepts and new ways of learning and teaching, the flexibility to review and analyze possible failures during this journey should be shared.

Facing the challenges exposed, one considers as necessary a systematic monitoring of the implementation of an educational project of a course, which should cope with provocations and bring innovation in the technology of nursing education. Thus, the objective of the study was to monitor and describe the process of implementation of the pedagogical project of the undergraduate nursing course at the Campus of Catalão, Federal University of Goiás, from the perspective of professors and students by means of a group strategy.

\section{Method}

This was a qualitative descriptive study. The research setting was the undergraduate nursing course in the campus of Catalão, Federal University of Goiás, approved by the National Education Council's ordinance number 3/2001 in 2008. The meetings were held in places reserved exclusively for the research.

Thirteen subjects from the undergraduate nursing course, who were randomly invited, participated in the research. It was adopted as an inclusion criterion for professors to be linked to the undergraduate nursing course and for students to be enrolled in the course. One opted for the participation of professors and students for understanding that they act actively and are key participants in the implementation process of the course.

Data collection occurred from April 2010 to June 2011. One used the focus group as technique with theoretical and methodological orientation for the operating group proposed by Pichon-Rivière ${ }^{(5-6)}$.

It is recommended that a focus should have 
from six to twelve participants, so that the issues can be addressed in greater depth and so that group interaction can occur. In larger groups, one runs the risk of limiting the participation of members and minimizing the exchange of ideas ${ }^{(7-8)}$. Thus one understands that the small difference (one subject) between the total number of participating professors and students does not constitute an element of research bias, since in every meeting the number of participants fluctuated for more or for less.

The choice of the operating group as a reference occurred because it is a group focused on a task that mobilizes collective learning in an organization of reviewing learning matrices that end up showing individual and group resistances. According to Pichon-Rivière, the operating group acts as a modifier instrument of reality from the moment when the members establish group relationships, sharing common goals and realizing how this interrelationship between the members belonging to the group occurs $^{(5)}$.

The operating group had as a strategy the recording and reading of group happenings, which enabled an assessment in process ${ }^{(6)}$. For the implementation of the operating group there were also a coordinator and two observers. Both roles provided in an operating group are asymmetric in relation to the others. The coordinator basically serves to encourage dialogue, aiming at communication and learning promotion when dealing with group conflicts. The observer helps the coordinator and is responsible for capturing the verbal and non-verbal expressions in the group field, which will improve the evaluation and conduction of the group by the coordinator ${ }^{(9)}$. Thus, the material produced by the observer consisted of a field journal that helped analyze the meetings and final data analysis.

As a procedure for the development of the meetings of the operating group during data collection, it was established at the first meeting the contract-goal of the study and of the group, with information about the duration, location and means of dissemination of the meetings, the operating group's purpose in the monitoring of the pedagogical project's implementation of the course and research. For other meetings of the operating group, it was adopted the chronicle of the previous meeting as a triggering theme for the start of each new meeting.

The chronicle is a document written by the coordinator and the observers at the end of each meeting, contemplating a synthesis of the opening, development and closure of the meetings, highlighting the issues considered, the group results, the communication, the cooperation between the parties and the roles explored.

The chronicle was used for data analysis. In order to preserve the identity of participants, the subjects were described by colors. They were analyzed through the content analysis, thematic modality, because it is characterized as one that explores the data and their meanings, including pre-analysis, material exploration, and treatment of the results ${ }^{(10)}$.

An informed consent form was signed after the clarification of the possible risks and benefits to participate in the research. The research project that supported this study was approved by the Ethics Committee of the Federal University of Goiás, protocol number 026/2009.

\section{Results}

Out of the thirteen subjects in the research, six were students who were in the third and the fifth semester of the nursing undergraduate course and seven were professors. Out of these, six were permanent professors with exclusive dedication and one was a professor with a temporary contract, six had majored in nursing and one in pharmacy. The age of the subjects studied ranged from 18 to 40 years old. There was a predominant participation of females composed of eleven individuals.

Seven meetings were held throughout the semesters, as shown in Figure 1, following the implementation of the nursing course. 


\begin{tabular}{|c|l|}
\hline Meeting & Triggering theme of the group task \\
\hline 1 & Presentation of the research project. \\
\hline 2 & Interpersonal relationships and conflicts. \\
\hline 3 & $\begin{array}{l}\text { End of the first semester with the implementation } \\
\text { of Course's Pedagogical Project. }\end{array}$ \\
\hline 4 & $\begin{array}{l}\text { Weaknesses for the implementation of the Course's } \\
\text { Pedagogical Project in the second year of the course. }\end{array}$ \\
\hline 5 & $\begin{array}{l}\text { Professor and student: the transposition of } \\
\text { theoretical knowledge in a practical scenario. }\end{array}$ \\
\hline 6 & $\begin{array}{l}\text { Self-reflection on the characteristics of each group } \\
\text { member with their advantages/disadvantages. }\end{array}$ \\
\hline 7 & $\begin{array}{l}\text { How did the creation of the course subjects and } \\
\text { their remodeling happen throughout the course? }\end{array}$ \\
\hline
\end{tabular}

Figure 1 - Number of meetings and the contents used as triggering themes of the group task

As a result one obtained eight chronicles, and from their analysis process a central category emerged "The Pedagogical Project of the Nursing Course: the group as an approach of the limitations and potentialities", and the subcategories "The group as a tool to cope with stereotypies and resistance" and "The group as a space for reflection about potential factors for teaching". They revealed the work group and its management, the interdisciplinary of the curriculum and the maturity process of the student-professor relationship as central axes of the discussion, indicating the group as a promising space for approach and reflection of conflicting situations.

\section{The group as a tool for dealing with the stereotypies and resistance}

In this category, phenomena and factors that indicate difficulties in the implementation process of the pedagogical project in the course of study are highlighted.

As one of the factors, the students' maturity was described: Yellow indicates that students have several concerns when they are in the classroom space, they are often not fully present, they worry about other things, such as home, finances, personal relationships, tests and cannot concentrate. They usually need contact with the practical part to see that they need to dedicate themselves more to study, and their individual effort is what motivates this (Chronicle V). Students' immaturity due to their enrollment in higher education younger and younger has been approached in Orange's speech, she says that the professors see themselves with the responsibility to introduce students to this new reality, which is often different from the ones they were used to (Chronicle I).

In this case, immaturity can lead the student to present several limitations on the co-responsibility for the success of the teaching-learning process and in the management of the study itself. However, this phenomenon cannot make the student to be considered a scapegoat in relation to learning, it is necessary that the professor and the course in general are prepared to deal with the youngsters' realities and needs.

Students receive the group anxiety and reached the status of scapegoats for the difficulties encountered in the implementation of the course's pedagogical project, as verified: The most serious problem is the fact that they (professors) do not reflect critically about their problems, students are often seen as the guilty ones with no selfcriticism (Chronicle III). Then the student should not be taken as the guilty ones due to the professors' laziness, who do not have interest in looking at students in a more humane way, admitting their flaws and their problems (Chronicle I).

Another phenomenonalso covered in the groups and that is often at the center of the conflicts involving the teaching-learning process there is the studentprofessor evaluation, as evidenced: Rosa was angry and disappointed with the way she was evaluated, and points out that the way the assessment is made gives students some "protection" to give a score lower than the one deserved and that it could be different if that evaluation was done face-to-face (professor/student) (Chronicle III); The Coordinator says that the evaluation process should not be seen as arm-wrestling between professor/student, if the student receives a grade that he does not like, he reciprocates the same way, giving this professor also a bad grade (Chronic III). Blue indicates voids or problems in the relationship with students, he refers to this when there is misinterpretation accompanied by aggressiveness when, for example, he demands corrections in academic papers, and the lack of boundaries in the professor-student relationship (Chronicle V).

The assessment can also become a tool of terror and punishment in student-professor relationship 
and not a valuable tool for the training of future professionals. When there is a lack of knowledge about the power of the phenomenon 'assessment', a disregard of their education and training effects prevails, then it starts be used exclusively in a different way, far from the complex teaching practices, thus it is a stereotypical conception of this relationship that stiffens and depletes the teaching and learning process.

In this context (teaching-learning process in nursing), intense issues are experienced by students as the transition phase of life from adolescence to adulthood, by coping with changes associated with relationship conflicts between professors and students. These aspects were discussed and recorded in the chronicles of the operating group, thus representing a space that fostered reflection on factors that could impact positively or negatively in the process of knowledge construction. In the excerpts of the chronicles, one verified: It is really necessary that the professor guides the student properly, not leaving him unattended and without clarification, looking for possible failures and points to be improved (Chronicle III). It is important the mutual development of professors and students, because they will become builders of knowledge (Chronicle III). Green insists that such dialogue between students/professors should happen to prevent or resolve possible problems (Chronic IV).

\section{The group as a space for reflection about potential factors of teaching}

As a potential factor for the teaching of nursing, it was evident during the chronicles' analysis the interdisciplinarity in the curriculum. The importance lies in the articulation and aggregation of college subjects. In this sense, the discussion in the operating group mobilized the reflection of the research individuals, in a movement to value each college subject of the curriculum in the context of nursing education. This integration was identified as a facilitator for students' learning, and this integration between college subjects happens according to Blue, because of the empathy between professors and the ideologies of the subjects involved (Chronicle I). Green says that student often do not understand how important this interaction among subjects is, and emphasizes that it is very important in the training of a professional nurse (Chronicle I). Purple relates Care Process I, Public Health I and Anthropology I saying that they are subjects that interact among themselves (Chronicle IV).

In the narrative of the group, it was observed that the interdisciplinarity of the curriculum was discussed as a way of articulating the knowledge necessary to understand the real situations of the health work reality. There have been proposals to use active pedagogies that support the construction of the pedagogical project of the course and in the group its actors identified the importance of this process and have reported some concrete joints between different areas of knowledge during the nursing training.

The group meetings provided the reflection of the factors that lead to the deployment and consolidation of the pedagogical project of the course, as well as led to the identification of the potential of group work, applied to students as a pedagogical practice in nursing professional education. Working with students in small groups favored their understanding, creating an environment of belonging and satisfaction with learning (Chronicle II).

Group work in education is important, but it requires preparation with a view that has also its challenges for the educator. The challenge of working in groups is to create favorable and comprehensible circumstances and environment to everyone, as well as conditions of autonomy and independence for them to manage their own study (Chronicle V).

Another reflection that permeated the discussions in the group, in order to favor the training of the student through the new pedagogical project of the course was the relationship between theory and practice. The more these two dimensions of education are synchronous and complementary, the better the conditions of learning in the participants' opinions are. Lilac highlights that the theory combined with practice becomes a facilitator for learning (Chronic I), and Blue starts the discussion by pointing the use of project methodology as a resource to combine practice and theory (Chronicle $\mathrm{V}$ ). 


\section{Discussion}

Many college students are in a time of transition during the undergraduate course, for example, in relation to the phases of life of being a teenager and becoming an adult ${ }^{(11)}$. Therefore, one should consider that the inherent changes in the dynamics of requirements, routines and roles assumed that occur within their university life influence nursing students' quality of life. Therefore, it can be facilitated through an inter-relationship among the students' adjustment within the university environment, the situational events and the changes experienced by them in many different contexts. Academic life allows students to conquer a new identity because they live away from home and from their families and due to the new responsibilities assigned to them ${ }^{(9)}$.

This situation brings to students basic fears, arising from the anxiety generated due to a new situation, an unexpected one, emerging from the need to adapt to this new reality, and then, a restructuring of their bonds. With this need to adapt there is a fear of losing their existing bonds, which is added to cope with the new situation, to which the individual might not be prepared. It is not uncommon to arise too much resistance to change when they are faced with such challenges ${ }^{(12)}$, a moment when they need a more understanding approach towards their experience.

The behavior of making students receive the anxiety created within the group to enforce the implementation of the course's pedagogical project might lead to barriers as a form of defense, which only contributes to resistance to change. For scholars this condition of resistance comes from a crystallization behavior around concepts and way of being and acting, which is not promising to make transformations a factor, then prevailing a stereotyped status ${ }^{(5-6,9-12)}$.

Moreover, there are distortions regarding the purpose of instruments and stages which involve the teaching and learning process, such as the evaluation. It has been conceived and experienced as an instrument of power in the organization of the curricula of undergraduate courses. A naive attitude towards this phenomenon cannot be accepted anymore, therefore requiring from higher education professionals the development of expertise to handle all the situations involving this aspect of teaching ${ }^{(13)}$.

In the professor-student relationship for various reasons there are situations that mobilize fear, insecurity and tension. Certainly there are conditions that harm the teaching and learning process, particularly when it is focused on a poor relationship of dialogue and disregard of the limitations and difficulties inherent in nursing education. Then there is a dichotomy between theory and practice in which professors are not often prepared to deal with criticism from students and adopt defensive postures in relation to them, when there isn't a welcoming attitude of the professor towards the student or when he is exposed in class $^{(9)}$.

From the data analyzed, it was verified that the process of professional training involves the need to welcome students in their weaknesses as an attitude of promoting maturity. There is the sharing of attitudes in this relationship and in the affective-cognitive interaction, then learning goes beyond the technical and scientific context, because teaching involves con$\operatorname{cern}^{(14)}$.

To overcome this stereotyped state of interrelations, the operating group is indicated, given its intense network of interaction among individuals in the group. A group approach with this magnitude provides assertive learning relations, a situation of confronting resistances and prone to change. Put in other words, in the dialectic approach between the subject and the object by means of continuous communication and group interaction, there is an overlap of a unilateral, stereotyped and crystallized view $^{(5)}$, jumping qualitatively and expanding the quality of relationships with it, with each other and with the environment.

Thus, group work and in particular the 
operating group is considered a dimension of learning as a tool for dealing and coping with stereotypies in education ${ }^{(15)}$.

This type of activity enables the interaction of experiences, since people perform their activities mainly in groups. The relationships between human beings and the dynamics of inter-group processes are the pillars that guide the interaction of people among each other(15-16). In a group coexistence, the relationship among individuals in a way that there are interpersonal interactions among the people involved, which contributes to the modification of their own abilities or the other members', thus there is a qualitative growth of both actors in this process of mutual interaction ${ }^{(5)}$.

Thus, the methodology of working in small groups contributes, facilitating the teaching-learning process, since both the professor and the student get closer during this practice in a classroom, as evidenced by the results of the research participants. In this perspective, it is emphasized the need for professors to master and apply group techniques when conducting the teaching process in nursing ${ }^{(17)}$.

It is a fact that learning occurs through a continuous process and that communication and interaction with others are inseparable elements. The relationship with others allows a different constitution of knowledge, interactions and questions about oneself and the others involved in this construction process $^{(5)}$.

The peculiarities relating to the thoughts and motivations of each individual must be considered and it is important to bear in mind that, when one decides to coordinate a group, he should expect to cope with diversity and differences of interest ${ }^{(18)}$.

When considering the field of nursing, it is worth remembering that nurses are inserted into different groups throughout their professional everyday practice, and these groups might be composed of their team or their patients. This methodology of working in groups will assist professionals to develop specific knowledge, preparing them for inter-relationship with their teams and/or patients who will be under their management and care ${ }^{(15)}$.

Thus, it is understood that in the teachinglearning process there is an interdependence between professors' and students' practices, aiming to work together when they share their responsibilities in this process. In the lively and dynamic space in which the pedagogical project of course occurs, group work stood out as a didactic-pedagogical method.

The contribution of various scenarios for learning favors nurses' training, involving theoretical knowledge articulated to the practical one. Added to this, based on the guidelines, it is the educational institutions' duty to provide to students an approach to teaching that includes not only variations in educational activities, but also in the form the content is taught, in the processes of evaluation and practical learning ${ }^{(4,19)}$. There should be also the use of strategies that emphasize the students' immersion in the context of the population's health in different scenarios during classes.

Thus, educational institutions, health services and the community need to be constantly in conversation and close to one another to foster training in line with the guidelines of educational policies for training of health professionals in Brazil.

\section{Final Considerations}

The application of the operating group as a research strategy represented a space to control anxieties that emerged in the process of implementation of a course's pedagogical project, as well as through group exchanges it enabled the identification of weaknesses and strengths that occurred in this process, thus representing an assertive space to accompany concerns, obstacles and success achieved, such as the creation of conditions to discuss the importance of interpersonal relationships in the teaching-learning process.

Some strengths of the course studied were highlighted such as the stimulus of teaching practices 
that promote the use of small groups and the insertion of students in teaching practice situations in the initial semester of the undergraduate course in different scenarios.

All these factors show that managers of higher education institutions should invest in training for professors about the understanding of learners' maturation process and group work. Because then they may use the operating group as a resource for diagnosing and monitoring the implementation process and evaluation of courses, as a research and teaching procedure, since it is an element that brings reflections and changes to the subjects who participate in it.

However, the limitations of the study are recognized as it represents a given reality, thus one encourages the continuity of research for monitoring the implementation process of courses' pedagogical projects, especially in federal institutions of higher education since they undergo significant changes and are not always accompanied by the qualitative level.

\section{Collaborations}

Carvalho GCG, Leonel LCPC, Lucchese R and Fernandes CNS contributed to the study design, collection, analysis and interpretation of data, drafting of the article and final approval of the version to be published. Souza MCBM contributed to the article's drafting and final approval of the version to be published.

\section{References}

1. Fernandes JD, Teixeira GAS, Silva MG, Florêncio RMS, Silva RMO, Rosa DOS. Expansion of higher education in Brazil: increase in the number of undergraduate nursing courses. Rev Latino-Am Enfermagem. 2013; 21(3):670-8.

2. Pereira TI, Silva LFSC. As políticas públicas do ensino superior do governo Lula: expansão ou democratização? Rev Debates. 2010; 4(2):10-31.
3. Lucchese R, Vera I, Pereira WR. As políticas públicas de saúde - SUS - como referência para o processo ensino-aprendizagem do enfermeiro. Rev Eletr Enf. [periódico na Internet]. 2010; 12(3):562-6. Disponível em: http://www.fen.ufg. br/fen_revista/v12/n3/v12n3a21.htm.

4. Keiser DE, Serbim AK. Diretrizes curriculares nacionais: percepções de acadêmicos sobre a sua formação em enfermagem. Rev Gaúcha Enferm. 2009; 30(4):633-40.

5. Bastos ABBI. A técnica de grupos-operativos à luz de Pichon-Rivière e Henri Wallon. Psicólogo inFormação. 2010; 14(14):160-9.

6. Lucchese R, Barros S. A utilização do grupo operativo como método de coleta de dados em pesquisa qualitativa. Rev Eletr Enf. [periódico na Internet]. 2007; 9(3):796-805. Disponível em: http://www.revistas.ufg.br/index.php/fen/ article/view/7505/5323.

7. Gatti BA. Grupo focal na pesquisa em ciências sociais e humanas. Brasília: Líber Livro; 2005.

8. Barbour R. Grupos Focais. Porto Alegre: Artmed; 2009.

9. Leite SAS. Afetividade nas práticas pedagógicas. Temas Psicol. 2012; 20(2):355-68.

10. Bardin L. Análise de Conteúdo. São Paulo: Edições 70; 2011.

11. Sampaio FFJL, Sousa PRM, Vieira NFC, Nóbrega MFB, Gubert FA, Pinheiro PNC. Percepção de risco de adolescentes escolares na relação consumo de álcool e comportamento sexual. Rev Gaúcha Enferm. 2010; 31(3):508-14.

12. Pichon-Rivière E. 0 processo grupal. 8 ${ }^{\underline{a}}$ ed. São Paulo: Martins Fontes; 2009.

13. Sordi MRL, Ludke M. Da avaliação da aprendizagem à avaliação institucional: aprendizagens necessárias. Avaliação. 2009; 14(2):313-36.

14. Guedes GF, Ohara CVS, Silva GTR. Intensive care unit: a significant space for the professor-student relationship. Acta Paul Enferm. 2012; 25(2):14650.

15. Grando MK, Ferreira SR, Dall'Agnol CM, Olschowsky A. El interjuego de papeles em el processo enseñanza-aprendizaje a partir de La 
técnica de grupo operativo. Rev Panamericana Enferm. 2005; 3(2):146-52.

16. Fernandes CN, Munari DB, Soares SM, Medeiros M. Habilidades e atributos do enfermeiro como coordenador de Grupos. Rev Rene. 2008; 9(1):146-53.

17. Borbato RG, Correa AK, Souza MCBM. Aprender em grupo: experiência dos estudantes de enfermagem e implicações na formação profissional. Esc Anna Nery. 2010; 1(14):48-55.

18. Cardodo ASF, Dall'Agnol CM. Group process: reflection of a nursing team. Rev Esc Enferm USP. 2011; 45(6):1406-12.

19. Guerra ST, Prochnow AG, Trevizan MA, Guido LA. Conflict in nursing management in the hospital context. Rev Latino-Am Enfermagem. 2011; 19(2):362-9. 